\title{
Benefits of dedifferentiated stem cells for neural regeneration
}

\author{
Yinda Tang ${ }^{1,2,3 \#}$, Wen $\mathrm{Xu}^{4 \#}$, Haiying Pan ${ }^{1,2}$, Shiting $\mathrm{Li}^{3}$, Yong $\mathrm{Li}^{1,2^{\star}}$ \\ ${ }^{1}$ Department of Pediatric Surgery, School of Medicine, University of Texas, Houston, USA; \\ *Corresponding Author: Yong.Li.1@uth.tmc.edu \\ ${ }^{2}$ Center for Stem Cell and Regenerative Medicine, The University of Texas Health Science Center at Houston, Houston, USA \\ ${ }^{3}$ Department of Neurosurgery, Shanghai Xinhua Hospital, School of Medicine, Shanghai Jiao Tong University, Shanghai, China \\ ${ }^{4}$ Center for Neuroscience, University of Pittsburgh, Pittsburgh, USA
}

Received 11 April 2012; revised 11 May 2012; accepted 10 June 2012

\begin{abstract}
Dedifferentiation, as one of the mechanisms rerouting cell fate, regresses cells from a differentiated status to a more primitive one. Due to its potential of amplifying the stem/progenitor cell pool and reproducing sizable and desirable cellular elements, it has been attended in the field of regenerative medicine, which will hopefully provide novel therapeutic strategies for currently incurable diseases, such as varieties of central nervous system (CNS) diseases and injuries. In this article, we will first discuss naturally occurring and experimentally induced dedifferentiation, and then set forth principles in stem-cell based therapy in the neural field; beyond that, we will introduce two recent studies that show dedifferentiated stem cells contribute to neural regeneration. Moreover, we also present our recent research results of dedifferentiated muscle stem cells for neurogenic differentiation study in vitro. Further work will be conducted to elucidate the mechanism underlying the dedifferentiation process to facilitate the development of new strategies in regenerative medicine.
\end{abstract}

Keywords: Dedifferentiation; Neural Stem Cells; Muscle Stem Cells; Neurogenesis; Regenerative Medicine

\section{DEDIFFERENTIATION, A POTENTIAL APPROACH INVOLVED IN REGENERATIVE MEDICINE}

The ability of animals to regenerate lost tissues is a dramatic and poorly understood aspect of biology. The sources of the new cells and the routes to these regenera-

\#Authors contribute as the first author. tive phenomena have been sought after for decades. Dedifferentiation, which is one process involved in natural regeneration, refers to the reversion of a terminally differentiated cell back to a less differentiated stage within its own lineage as part of regenerative process. It was first used to describe ascidian stolon regeneration in 1902 [1] but there was little evidence for this concept besides cellular morphology. Since then, intensive studies have been carried out in this field and accumulating evidence of this naturally occurring process has emerged from lower organisms as well as from mammalian tissues; this evidence will shed light on the basic mechanism underlying regeneration and aid in conceiving new strategies in regenerative medicine.

In non-mammalian vertebrate species, complete regeneration of zebrafish heart following ventricle amputation can be achieved by dedifferentiation of cardiomyocytes through disassembling the sarcomeric contractile apparatus, which contains a large proportion of terminally differentiated cells that physically impede cytokinesis [2-9]. Another intensively studied case is the blastema formation after limb amputation in the urodele amphibians. Shortly after limb amputation, cells adjacent to the wound dedifferentiate and form a blastema that consists of undifferentiated cells, which subsequently proliferate and eventually redifferentiate to create all the components of the lost limb [10-17]. In mammals, evidence of dedifferentiation has also been observed. In the case of peripheral nerve injury, Schwann cells are capable of dedifferentiating and proliferating when they lose contact with the axon that they are myelinating [18-21]. Astrocytes, another type of mature glial cell, can upregulate proteins that are characteristic of neural stem cells (NSCs) and re-enter the cell cycle after brain injury [22-30]. As determined in vitro, a fraction of these reactive astrocytes also shows long-term self-renewal and multipotency by forming neurospheres [22]. Another recent study showed that reversion of spermatogonia to germline stem cells 
occurs in the murine spermatogenic compartment [3133]. Most recently, using an ingenious cre/lox system, our research demonstrated for the first time that dedifferentiation of skeletal muscle cells to early progenitor cells, including myoblasts and muscle-derived stem cells (MDSCs), occurs in an injured mouse model in vivo and can enhance cell proliferation and myogenesis [34].

In addition to the evidence demonstrating that dedifferentiation takes place naturally under certain stresses in a wide spectrum of species, recent studies have also clearly shown that this process can be achieved by experimental induction. After treatment with the extract isolated from regenerating newt limbs, mouse myotubes reduce the expression of the myoblast determination genes MyoD and myogenin, and subsequently dedifferentiate and proliferate [35]. Similarly, another group has shown that small chemical molecules can dedifferentiate lineagecommitted myoblasts to multipotent mesenchymal progenitor cells, which can further go through adipogenesis and osteogenesis to generate fat cells and bone cells, respectively $[36,37]$. There are also examples of more dramatic dedifferentiation induction resulting in even pluripotency. A plethora of differentiated cell types can be induced to undergo an almost complete reprogramming through overexpression of a cocktail of transcripttion factors, generating induced pluripotent stem cells (iPS cells) [38-42], which can be argued as the ultimate form of dedifferentiation by a broader definition, that is, a developmental event involving reduction in the molecular and/or functional properties of a differentiated cell type. According to this paradigm, cells might be "formatted" through dedifferentiation to a primitive status and then re-differentiate towards a new lineage to generate new types of cells. This lineage switch initiated through dedifferentiation makes it possible to use cell types that are relatively accessible and numerous in order to replace lost cell types that are scarcer and difficult to obtain through the progenitor cells of their own lineage. Given this possibility, some promising strategies might be conceived for the cell-based therapy for intractable diseases in certain organs and systems, such as the injured or degenerated central nervous system (CNS).

\section{REGENERATION IN CNS: NEURAL STEM CELLS AND ADULT NEUROGENESIS}

With respect to other organs, the CNS shows structural peculiarities, and owing to the relative lack of recovery from CNS injury, the dogmatic view of a "fixed, ended and immutable" neural tissue in mammals has been prevalent since the early 1900s [43-45]. The word "regeneration" in neuroscience was originally restricted to axonal regeneration by surviving cell bodies after in- jury [46-48]. Along with early emerging evidence of ongoing cell division in adult mammalian brain [49-51], technical advances such as the use of the S-phase marker Bromodeoxyuridine (BrdU) [52-54], the development of immunocytochemical reagents that could identify the phenotype of various neural cells [55-57], and more recently, the delicate manipulation of genetic methods for cell labeling and mutation, have led to an explosion of research in the field [58-60]. After Reynolds and Weiss showed in 1992 that precursor cells could be isolated from the forebrain and differentiate into neurons in vitro [61], neural stem cells (NSCs) have been characterized as self-renewing, proliferative and multipotent for the different neuroectodermal lineages of the CNS, including the multitude of neuronal and glial subtypes $[62,63]$. Since then, the meaning of the word "regeneration" in CNS could be extended from axonogenesis and synaptogenesis to the replacement of lost cells with newly generated elements coming from stem/progenitor cells, i.e., adult neurogenesis. Such a possibility for cell renewal theoretically brings our nervous system into the context of regenerative medicine. However, before developing new strategies to figure out efficacious therapeutic approaches, it is a crucial point to determine how NSCs and adult neurogenesis provide the CNS with regenerative potential.

Adult neurogenesis is regulated by physiological and pathological activities at all levels, including the proliferation of adult neural stem cells or progenitors, differentiation and fate determination of progenitor cells, and the survival, maturation, and integration of newborn neurons. In normal conditions, adult neurogenesis has consistently been found to be restricted within two small germinal layer-derived areas, e.g., the Subventricular zone (SVZ) of the lateral ventricles and the Subgranular zone (SGZ) in the dentate gyrus of hippocampus [64-67]. In the remaining CNS parenchyma, local progenitor cells might support a "potential" neurogenesis, which in spite of their proliferative capacity and retention of potentialities in vitro, they do not perform neurogenesis in vivo $[68,69]$. Meanwhile, other studies believe that some local parenchymal progenitors actually sustain spontaneous neurogenesis in vivo. For example, in rodents and even some non-human primates, some newly generated neocortical neurons have been found [70-72], as well as some neurons of the piriform cortex originating from $\mathrm{Ng}^{2+}$ progenitor cells [73-75]. Thus, whether neurogenesis occurs in areas outside of the two widely accepted "neurogenic regions" remains controversial $[76,77]$.

After unraveling the neurogenic potential in normal adult mammalian CNS, the question of how the neural stem/progenitor cells behave in different injury/pathological contexts need to be addressed. Although topographically restricted, neurogenic sites in mammalian 
brain that are active throughout life can react to injury [78-81], and adult neurogenesis may also be substantially augmented in neurodegenerative diseases $[82,83]$. For instance, experiments carried out in rodent models of stroke revealed that reactive neurogenesis does occur from the SVZ, leading to increased cell production and migration of neuronal precursors to the lesion site $[79,80]$. In addition to reactive neurogenesis from stem cell-containing "neurogenic regions", accumulating evidence indicates that different paradigms of brain lesion can induce neurogenic events from the local progenitors resident in normally "non-neurogenic sites", including the neocortex [84-86], striatum [87-89], amygdale [90], hypothalamus $[89,91,92]$, substantianigra $[93,94]$ and brainstem [95-97]. For example, local progenitors that are in a relatively quiescent state in layer I of the rat cerebral cortex were activated after ischemia, giving rise to new cortical interneurons [86]. These examples support the hypothesis that the mature CNS parenchyma may retain a latent stem/progenitor cell potential that is normally inhibited in vivo, but that, if properly evoked, might be exploited in situ for cell replacement.

\section{STRATEGIES AND CHALLENGES FOR NEURAL REGENERATION WITH STEM CELLS}

Given their ability to generate neuronal and glial cells in response to damage, neural stem cells are believed to play a core role in cell-based therapy for various neurobiological disorders, ranging from acute injury such as brain trauma and stroke, to chronic neurodegenerative diseases including Alzheimer's Disease (AD) and Parkinson's Disease (PD), all of which are characterized by neuronal loss. As described above, it can be concluded that the brain has an endogenous regenerative potential and that in some pathological conditions, it becomes more permissive. Based on this point, one conceivable strategy for neural regeneration is to enhance the endogenous neurogenesis in situ $[73,78,85,86,98,99]$. The advantage of this approach is that it takes advantage of the intrinsic potential of endogenous neural stem/progenitor cells, and as a result, is less invasive and has fewer side effects in comparison with strategies relying on cellular transplantation [100-103], which will be discussed later. However, in most cases, such neurogenic potential cannot be utilized in a successful way. First, the magnitude of the neurogenic response to injury appears small, and it remains unclear as to what extent this is, because new neurons fail to develop at a sufficiently rapid rate versus cell death prior to sufficient integration into the host environment. In one case of brain injury, the great majority of the newborn cells survive $<1$ month, and fail to replace lost neuronal populations and to re store damaged neuronal circuits [104]. Newly born neurons could replace only $0.2 \%$ of the dead striatal neurons in another rat cerebral ischemia model [79]. The exact mechanism for this overall inability of the endogenous stem cell compartment to promote full and long-lasting neural regeneration remains unclear. Recent data suggest that an altered neurogenic niche, including various overlapping local interactions between growth factors [105108], extracellular proteins $[109,110]$, metalloproteases [111-113], neurotransmitters [108,114,115], and angiogenesis [116-118], can be responsible for this failure. Even if enhanced cellular survival can be achieved, there are still significant impediments to neural maturation and integration, such as glial scar formation [119,120], cell death $[121,122]$, inflammation $[123,124]$ and aging $[125$, 126], all of which are topics of an open field of research. Although encouraging results from various experiments involving the administration of neurotrophin [127-129] or anti-inflammatory drugs [130-132] have shown some evidence that functional recovery is related to enhanced endogenous neurogenesis, the road ahead is still rocky and full of obstacles.

Paralleling this new understanding of endogenous neurogenesis, much progress has been made in the area of exogenous neuronal transplantation [100-103]. Early transplantation of embryonic midbrain tissue to the brain was first performed for PD and Huntington's disease (HD) in animal models as well as human clinical applications [133-136]. However, these experiments demonstrated a limited efficacy, along with other problems such as tissue availability and ethical questions. Today, it seems possible to achieve such therapeutic effects by using various sources of stem cells, due to their ability to replace the lost tissue as well as their "bystander" effects like neuroprotection and immunomodulation [101]. NSCs can be extracted directly from fetal or adult tissue via the dissection and digestion of CNS regions. In serum-free cultures with Epidermal growth factor (EGF) and Fibroblast growth factor 2 (FGF2), they can proliferate and spontaneously differentiate into both neuronal and glial cells after withdrawal of growth factors [61,137]. This possibility of stable expansion and in vitro differentiation into desired neural cells makes human NSCs an attracttive cell source for transplantation strategies. Fetal-tissue-derived NSCs are the only source of stem-cell-derived neural cells that have entered the clinical arena for treatment of Neuronal ceroidlipofuscinosis (NCL, Batten's disease) [138] and Pelizaeus-Merzbacher disease (PMD). Application of oncogene-immortalized NSCs [139] are also approved in a phase I clinical trial in the United Kingdom for stroke therapy. Results so far have been favorable and encouraging. Autologous NPCs obtained at the site of focal damage would be an even more attractive option since they avoid immunogenicity, al 
logenicity and ethical issues related to NSCs from other sources above [140]. The risk of tumor formation cannot be excluded and the long-term safety of such cells remains to be determined [141].

Embryonic stem cells (ESCs) are derived from blastocysts during the 16 cell stage and have an almost unlimited capacity to self-renew [142]. They can be expanded for many years and differentiated into neural stem or precursor cells and subsequently into brain cells, which makes them a feasible exogenous source [143-146]. On the other hand, ESCs also bear considerable teratogenic potential after implantation into host tissue, although protocols for inducing them into relatively pure differenttiated population before transplantation have been developed [147]. Immunosupression is also needed. In addition, immense ethical concerns exist regarding the use of human ESCs as well as government restrictions that continue to limit clinical applications [148].

The generation of iPS cells is considered the main breakthrough in regenerative medicine [38-42]. As mentioned in the first section in this article, these cells are reprogrammed via a thorough reversion from a terminal stageback to a pluripotent status, which can be considered a complete dedifferentiation. By re-differentiating along a neural lineage, such cells offer another autologous source that is ethically acceptable and eliminates the risk of immunological complications. However, these cells are also under risk of tumor formation, and safety cannot yet be guaranteed [149]. In addition, differences seem to remain between ESCs and iPS cells that render the differentiation of the latter cells into mature neurons much more difficult [150-152]. Therefore, their clinical application does not seem feasible in the near future. Most recently, induced neurons (iN) have been obtained by reprogramming adult somatic cells directly into mature neurons without the intermediate step of iPS cells [153-159]. Future studies are necessary to show whether it is possible to generate such specific neurons that are sufficiently mature for transplantation and also lack the risk of tumor formation.

Additionally, it has been shown that terminal neural differentiation can also be seen with non-CNS-derived multipotent somatic stem cells, such as mesenchymal stem cells (MSCs) [160,161], muscle stem cells (MuSCs) [162-164], placental cord blood stem cells [165,166], skin stem cells [167] and adipose derived stem cells $[168,169]$. These cells are relatively numerous and easy to collect from patients, presenting another autologous source without immune reaction. It is also possible that these stem cells provide trophic support to damaged neural tissue and as a result, enhances the endogenous approach [170]. However, the proof of functional neurons derived from MSCs has not been provided. Although there are already some ongoing clinical trials that show some pos sible clinical improvement [171], many questions concerning how to enhance their survival and the potential of neural differentiation remain to be addressed.

In summary, two main therapeutic strategies have been developed in neural regeneration. Exploring the potentialities of resident, endogenous adult stem/progenitor cells is an ideal approach for the future. In parallel, an intense effort has been made to produce stem/progenitor cells that could be used as transplantation tools so as to replace lost elements in pathologies. Immune reaction and ethical controversy are the primary issues related to the allogeneic approach of mainly utilizing embryonic/ fetal oriented cells, while the powerful iPS cells cannot avoid the risk of tumor formation and genetic instability. Figuring out how to enhance the survival, migration and neural differentiation potential of non-neural somatic stem cells will be the problem that needs to be resolved before these accessible autologous resources can be clinically applied.

\section{DEDIFFERENTIATED SOMATIC STEM CELLS, A BETTER SOLUSTION?}

Addressing the last point summarized above, we here introduce two lines of evidence that show dedifferentiation might contribute to the resolution. One is from our work that focuses on muscle stem cells (MuSCs), and the other one published most recently is related to mesenchymal stem cells (MSCs) [172]. They start from distinct approaches of induction of dedifferentiation, but they arrive at the same conclusion that dedifferentiated MuSCs or MSCs present improved neural regenerative potential.

\subsection{Dedifferentiation-Reprogrammed MSCs}

Hsiao Chang Chan and his group used a culture induction to perform dedifferentiation [172]. After establishing monoclonal MSC clones from primary rat bone marrow MSCs, they first initiated neuronal differentiation by transferring the clones into neuronal induction media and then returned them to stem cell characteristics by withdrawal of the induction media and reincubation in serum. These cells are considered dedifferentiated MSCs (DeMSCs). First, compared with uncommitted MSCs, DeMSCs are demonstrated to represent a previously undescribed distinct population of stem cells with several distinguishing features. Apart from the morphological and phenotypical similarity and the potential for multilineage differentiation into osteoblasts, adipocytes and chondrocytes, De-MSCs exhibit a predisposition to the neuronal lineages as demonstrated by both genetic and functional assays. Global gene expression profiling and PCR data show that dedifferentiated cells express in- 
creased levels of both neurogenesis-related genes and growth factors. The increase of nestin- and musashipositive cells in De-MSCs suggests that these cells carry additional neuronal potentiality that is ready to be activated under appropriate conditions, which is representative of an immature neural phenotype, most likely neural stem/progenitor cells. Taken together, De-MSCs appear to represent a distinct population of stem cells with a higher potential for re-differentiation into neurons compared to their original counterparts.

Next, they asked the question of whether or not DeMSCs have significant advantages over undifferentiated MSCs with respect to proliferation and survival. Indeed, proliferating cellular nuclear antigen (PCNA) staining confirmed that De-MSCs proliferated vigorously at 24 hours after dedifferentiation occurred and indicated this might be a result of acute reentry into the cell cycle. De-MSCs also exhibited a survival advantage over undifferentiated MSCs under conditions of hydrogen peroxide $\left(\mathrm{H}_{2} \mathrm{O}_{2}\right)$ oxidative stress, as demonstrated by FACS sorting analysis of Annexin-V/propidium iodide staining after $\mathrm{H}_{2} \mathrm{O}_{2}$ treatment. More importantly, they have found that De-MSCs maintained their anti-apoptotic properties after in vitro culture and passaging. Increased expression of bcl-2 family proteins was observed and appeared to play a role in the anti-apoptotic action. All of these results explained the observation of an increase in viable cells in De-MSCs compared to the uncommitted MSCs during the in vitro differentiation and dedifferentiation process and demonstrated that De-MSCs are advanced in cell survival and proliferation.

They went further to demonstrate the therapeutic advantage of De-MSCs in vivo in a rat model of neonatal hypoxic-ischemic brain damage (HIBD) via lateral ventricular transplantation of fluorescent cells isolated from GFP-transgenic animal. On day 7, GFP expression could only be detected in De-MSCs group, indicating improved cell survival. Moreover, a number of the surviving GFPDe-MSCs were found outside of the injection site, indicating migration of the cells. Immunostaining revealed that some GFP-positive De-MSCs expressed differentiated neuronal markers NF-M or MAP2, indicating neuronal differentiation from the De-MSCs in vivo. Of note, they also showed that the better survival of De-MSCs might lie in their greater ability to promote angiogenesis in the ischemic region. Finally, shuttle box tests confirmed a more significant improvement of functional recovery of HIBD animals after De-MSCs treatment. Taken together, these results indicated that De-MSCs had survival and neuronal differentiation advantages over undifferentiated MSCs under both in vitro and in vivo conditions. This makes them a promising cellular source in therapeutic strategies based on autologous transplanta- tion for neural regeneration.

\subsection{Update Study of Muscle Cell Dedifferentiation for Neurogenic Differentiation}

As mentioned at the beginning of our discussion on dedifferentiation, various studies in the amphibian limb regeneration field have demonstrated that dedifferentiation plays the core role by which the multipotent stem cells are generated via the formation of the "blastema" that conesquently regenerates the entire limb [10-17]. However, the occurrence of this process in mammalian skeletal muscle has been questioned, partially due to the contamination of other endogenous progenitor cells which might not be excluded using regular cell isolation techniques, leaving the possibility that they are the source of dedifferentiation rather than the terminally differentiated cells [173,174]. Therefore, as recently reported, we developed a conditional transgenic model based on cre/lox- $\beta$-galactosidase (gal) system to specifically and effectively isolate differentiated myofibers both in vitro and in vivo to obtain the purified source [34]. Using this model, we have successfully determined the superior myogenesis potential of the injury-induced dedifferentiated muscle stem cells (DeMuSCs) that were dedifferentiated from $\beta$-gal positive multinuclear myofibers in comparison with the non-injury counterpart. Moreover, some $\beta$-gal and CD31 (a marker for endothelial cells) dual positive signals were also found in the blood vasculation, raising the question of whether these De-MuSCs-could advantageously contribute to differentiation down other lineages, such as neurogenesis [34]. In the present experiment, we explored further with our previous novel cre/lox model in order to address this question.

De-MuSCs were obtained as previously described [34]. Briefly, Muscle Creatine Kinase-cre muscle derived cells (MCK-cre MDCs) and ROSA-lox- $\beta$-gal MDCs were implanted into the gastrocnemius (GM) muscles of SCID mice via intramuscular injection of equal populations. Three weeks later, a laceration injury was created at the cell implantation site in the GMs. Four days after injury, $\beta$-gal positive cells were isolated by flow cytometry. The pre-plate technique was then applied to isolate and expand the $\beta$-gal positive slow adhering cells (i.e., PP5 and PP6), which were convectively demonstrated to be DeMuSCs. We used primary mouse myoblasts, a muscle progenitor cell, as the control counterpart.

After isolation, both cell lines were kept in muscle cell growth media for one week before being transferred into NSC media for the induction of neurosphere proliferation. For further neural differentiation analysis, single cells were transferred into neural differentiation media. Cultured in NSC media, De-MuSCs successfully presented neural stem/progenitor characteristics. By day 3 in NSC 
media, some De-MuSCs had aggregated to form neurosphere-like structures that floated in suspension (Figure 1(c)), a hallmark of the structure of NSCs or neural progenitor cells, while control cells showed no signs of forming these special structures (Figure 1(a)). By day 6, the majority of the De-MuSCs were floating as spheres (Figure 1(d)), while the control cells still retained muscle cell morphology and stayed attached to the flask (Figure 1(b)).

The phenotype of the cells within the De-MuSCs derived neurosphere was analyzed by immunocytochemistry with typical neural markers. These spheres stained positive for Nestin, a marker for neural progenitor/stem cells, as well as the markers for more mature neural lineage cells: Glial fibrilllary acidic protein (GFAP) for astrocytes, CNPase for oligodentrocytes and Neurofilament (NFm) for neurons. EdU was detected in a select group of cells in each neurosphere (Figures 2(a)-(d)), indicating the proliferative status of these cells when cultured with mitotic reagents EGF and bFGF.

RT-PCR was performed on De-MuSCs and myoblasts, under both non-induced and NSC medium-induced conditions to detect changes that occurred on a transcripttional level. Within the non-induced group, the control cells had higher mRNA levels of myogenin compared to the De-MuSCs (Figure 3). In the induced group, both the control cells and De-MuSCs had lost myogenin mRNA expression (Figure 3). Meanwhile, nestin expression increased significantly for control cells and only slightly for MuSCs after NSC media induction (Figure 3). The expression of the stem cell marker Sca-1, which was absent in control cells and low in De-MuSCs at the beginning,

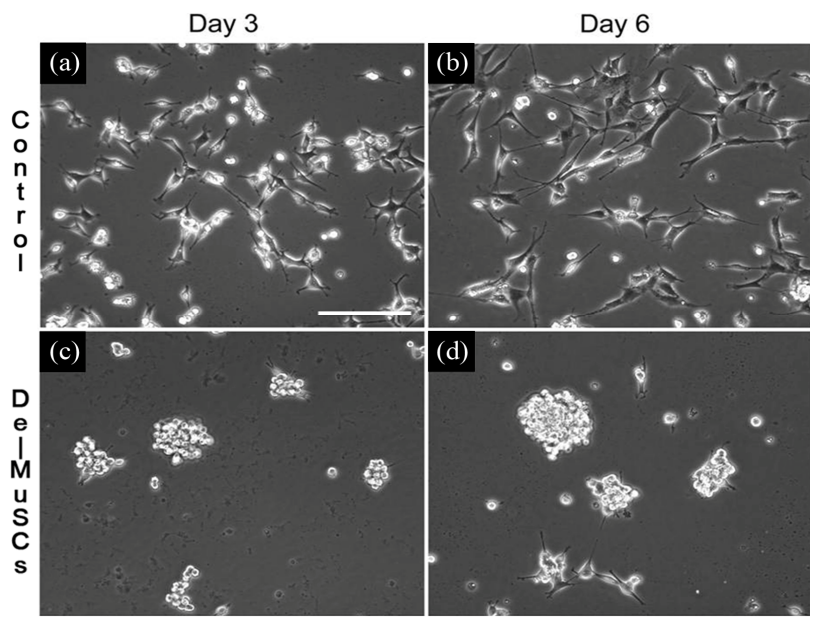

Figure 1. Results show that De-MuSCs Commit to Neural Lineage. Neurosphere-like structures were formed by De-MuSCs cultured in NSC proliferative media. De-MuSCs began to aggregate on day 3 (c) and presented morphology and architecture resembling that of neurosphere by day 6 (d), while the control primary myoblasts showed no signs of forming these structures (a)-(b) during these time period (3 and 6 days).
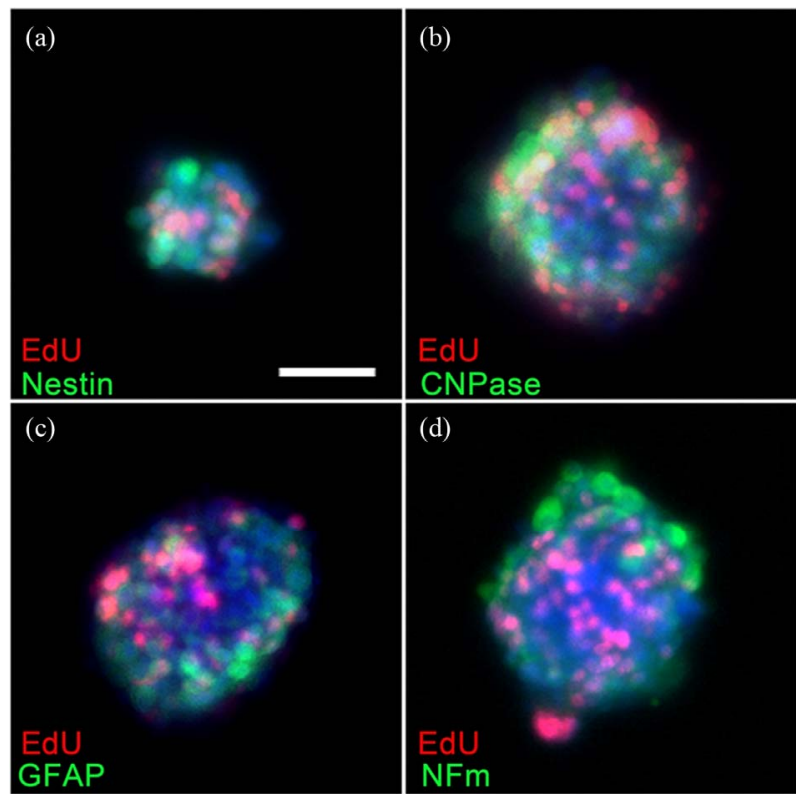

Figure 2. Immunocytochemistry showed the neural phenotype and proliferative status of the cells in the spheres that derived from De-MuSCs. On the fifth day after culturing in the NSC medium, these spheres stained positive for Nestin, a marker of neural progenitor/stem cells (a), as well as for other markers of mature neural cells, such as GFAP, NFm and CNPase (b)-(d). Mitosis assay performed 2 hours after EdU administration demonstrated the proliferative status of the cells in these spheres (a)-(d).

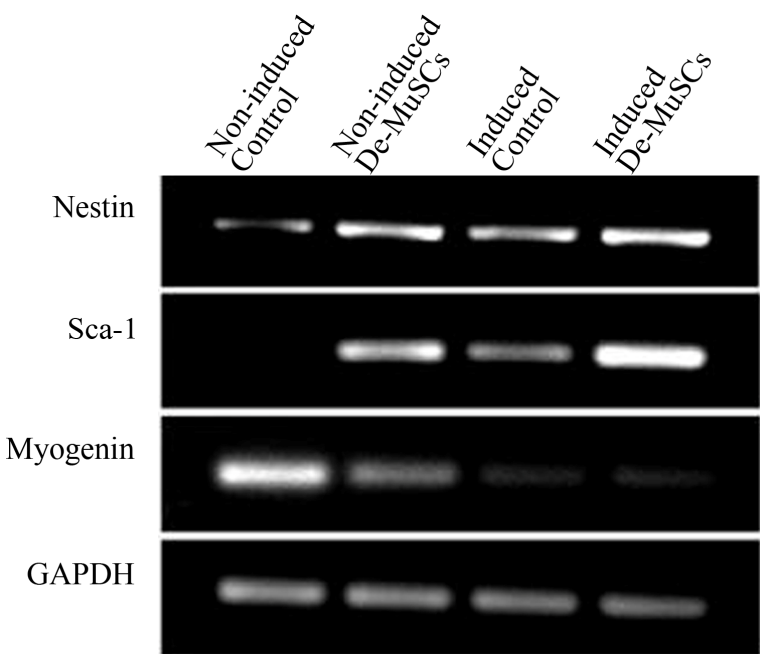

Figure 3. RT-PCR explored the alteration of the cell profile during culture with NSC medium. At the transcriptional level, the stem cell related markers Nestin and Sca-1 increased in both control cells and De-MuSCs after induction, although the De-MuSCs maintained a greater level. Meanwhile, the expression of Myogenin gradually decreased.

increased for both cell types after NSC medium induction (Figure 3).

As for neural differentiation (ND) induction, the DeMuSCs but not the myoblasts successfully differentiated 
into neural lineage cells. After 3 days in ND media, cells which were solely positive for NFM and possessed long, thin projections that resembled neuronal processes were observed. These cells were EdU negative, indicating their postmitotic status (Figure 4(a)). After 8 days, although some of the cells were positive for $\alpha$-smooth muscle actin ( $\alpha$-SMA), which might count for myofibroblast differentiation, the NFM positive cells were still detectable (Figure 4(b)). Meanwhile, other glial markers such as GFAP, CNPase were also positive in a subgroup of the cells, further suggesting the multiple potential of the De-MuSCs for neural differentiation.

In summary, our results potentially showed that DeMuSCs successfully formed neurosphere-like structures that contained neural stem/progenitor cells within NSC medium culture. RT-PCR confirmed that they were endowed with the capacity of differentiating along the neural lineage while they gradually lost myogenic potential. After being transferred into ND medium, De-MuSCs presented with neuronal morphology and immunophe

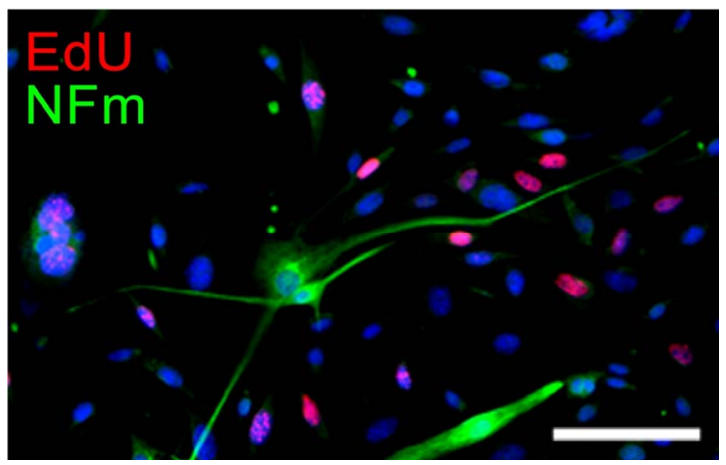

(a)

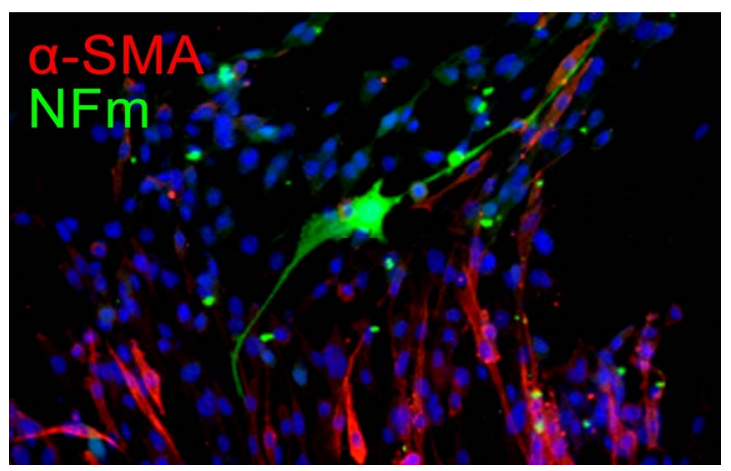

(b)

Figure 4. De-MuSCs differentiated into neuron-like cells after induction within ND medium. After 3 days in ND medium culture, some cells which were solely positive for NFm and possessed long, thin projections that resembled neuronal processes were observed. These cells were EdU negative, indicating their post-mitotic status (a); Eight days later, some of the cells began expressing for $\alpha$-smooth muscle actin ( $\alpha$-SMA), while there still scattered some NFm positive cells reminded scattered among the population (b). notype, confirming they became terminally differentiated neuron-like cells. Since our data implies that De-MuSCs have the potential to commit to the neural lineage, they may be able to aid recovery from neurological diseases by providing an easily accessible cell source for neural regeneration.

Taken together, the two studies above indicate that through various approaches, lineage committed somatic stem cells can be further dedifferentiated to a more primitive status, such as De-MSCs and De-MuSCs, which appear to have survival, proliferation, migration and neuronal differentiation advantages over their original counterparts under both in vitro and in vivo conditions. Because of the aforementioned characteristics as well as their accessibility, substantial population, and autologous orientation, they provide hope for finding a novel treatment strategy with improved therapeutic efficacy.

\section{CONCLUSION}

Regenerative medicine carries the responsibility of tackling various neurological diseases with limited treatment efficacies. Stem cell-based therapy can restore neural function by either enhancing the endogenous neurogenesis that is normally quiescent or replacing the lost cellular elements via exogenous transplantation of stem cell-derived cells. Dedifferentiation, as one significant approach involved in naturally occurring regeneration and experimental reprogramming, gives us more insight into these strategies. Among a variety of theoretically available cellular sources, dedifferentiated somatic stem cells with enhanced survival, proliferation, migration and neural differentiation in addition to easy accessibility and low tendency of tumor formation may offer an optimal solution. We introduced a recent study that depicted the advantages of De-MSCs along with our preliminary results that showed the remarkable superiority of De-MuSCs in neural regeneration. The detailed characterization of this novel stem cell population and the precise mechanism behind their beneficial effects still remain unclear, so further investigation must be conducted before the benefits of these stem cells can be clinically applied. However, the insight into dedifferentiation that we have already gained will bring us one step closer to finding effective bedside treatments for neurological disease.

\section{REFERENCES}

[1] Driesch, H. (1902) Studien über das regulationsvermögen der organismen. 6. Die restitution der Clavellina lepadiformis. Archiv für Entwicklungs mechanik, 14, 247-287. doi:10.1007/BF02162039

[2] Poss, K.D., Wilson, L.G. and Keating, M.T. (2002) Heart regeneration in zebrafish. Science, 298, 2188-2190. doi:10.1126/science. 1077857 
[3] Jopling, C. (2010) Zebrafish heart regeneration occurs by cardiomyocyte dedifferentiation and proliferation. Nature, 464, 606-609. doi:10.1038/nature08899

[4] Kikuchi, K. (2010) Primary contribution to zebrafish heart regeneration by gata4+ cardiomyocytes. Nature, 464, 601-605. doi:10.1038/nature08804

[5] Raya, A. (2003) Activation of Notch signaling pathway precedes heart regeneration in zebrafish. Proceedings of the National Academy of Sciences of USA, 100, 1188911895. doi:10.1073/pnas. 1834204100

[6] Sleep, E. (2010) Transcriptomics approach to investigate zebrafish heart regeneration. Journal of Cardiovasc Medicine, 11, 369-380. doi:10.2459/JCM.0b013e3283375900

[7] Lien, C.L., Schebesta, M., Makino, S., Weber, G.J. and Keating, M.T. (2006) Gene expression analysis of zebrafish heart regeneration. PLoS Biology, 4, e260. doi:10.1371/journal.pbio.0040260

[8] Lepilina, A. (2006) A dynamic epicardial injury response supports progenitor cell activity during zebrafish heart regeneration. Cell, 127, 607-619. doi:10.1016/j.cell.2006.08.052

[9] Ahuja, P., Sdek, P. and MacLellan, W.R. (2007) Cardiac myocyte cell cycle control in development, disease, and regeneration. Physiological Reviews, 87, 521-544. doi:10.1152/physrev.00032.2006

[10] Brockes, J.P. and Kumar, A. (2002) Plasticity and reprogramming of differentiated cells in amphibian regeneration. Nature Reviews Molecular Cell Biology, 3, 566-574. doi:10.1038/nrm881

[11] Echeverri, K., Clarke, J.D. and Tanaka, E.M. (2001) In vivo imaging indicates muscle fiber dedifferentiation is a major contributor to the regenerating tail blastema. Developmental Biology, 236, 151-164. doi:10.1006/dbio.2001.0312

[12] Odelberg, S.J., Kollhoff, A. and Keating, M.T. (2000) Dedifferentiation of mammalian myotubes induced by msx1. Cell, 103, 1099-1109. doi:10.1016/S0092-8674(00)00212-9

[13] Brockes, J.P. and Kumar, A. (2005) Appendage regeneration in adult vertebrates and implications for regenerative medicine. Science, 310, 1919-1923. doi:10.1126/science. 1115200

[14] Lo, D.C., Allen, F. and Brockes, J.P. (1993) Reversal of muscle differentiation during urodele limb regeneration. Proceedings of the National Academy of Sciences of USA, 90, 7230-7234. doi:10.1073/pnas.90.15.7230

[15] Kumar, A., Velloso, C.P., Imokawa, Y. and Brockes, J.P. (2004) The regenerative plasticity of isolated urodele myofibers and its dependence on MSX1. PLoS Biology, 2, e218. doi:10.1371/journal.pbio.0020218

[16] Kragl, M. (2009) Cells keep a memory of their tissue origin during axolotl limb regeneration. Nature, 460, 6065. doi: $10.1038 /$ nature 08152

[17] Nye, H.L., Cameron, J.A., Chernoff, E.A. and Stocum, D.L. (2003) Regeneration of the urodele limb: A review. Developmental Dynamics, 226, 280-294. doi: $10.1002 /$ dvdy. 10236
[18] Chen, Z.L., Yu, W.M. and Strickland, S. (2007) Peripheral regeneration. Annual Review of Neuroscience, 30, 209233. doi:10.1146/annurev.neuro.30.051606.094337

[19] Woodhoo, A. (2009) Notch controls embryonic Schwann cell differentiation, postnatal myelination and adult plasticity. Nature Neuroscience, 12, 839-847. doi:10.1038/nn.2323

[20] Mirsky, R. (2008) Novel signals controlling embryonic Schwann cell development, myelination and dedifferentiation. Journal of the Peripheral Nervous System, 13, 122-135. doi:10.1111/j.1529-8027.2008.00168.x

[21] Monje, P.V., Soto, J., Bacallao, K. and Wood, P.M. (2010) Schwann cell dedifferentiation is independent of mitogenic signaling and uncoupled to proliferation: Role of cAMP and JNK in the maintenance of the differentiated state. The Journal of Biological Chemistry, 285, 3102431036. doi:10.1074/jbc.M110.116970

[22] Buffo, A. (2008) Origin and progeny of reactive gliosis: A source of multipotent cells in the injured brain. Proceedings of the National Academy of Sciences of USA, 105, 3581-3586. doi:10.1073/pnas.0709002105

[23] Pekny, M. and Nilsson, M. (2005) Astrocyte activation and reactive gliosis. Glia, 50, 427-434. doi:10.1002/glia.20207

[24] Brown, A.M. and Ransom, B.R. (2007) Astrocyte glycolgen and brain energy metabolism. Glia, 55, 1263-1271. doi:10.1002/glia.20557

[25] Pekny, M. and Pekna, M. (2004) Astrocyte intermediate filaments in CNS pathologies and regeneration. The Journal of Pathology, 204, 428-437. doi:10.1002/path.1645

[26] Schmid-Brunclik, N., Burgi-Taboada, C., Antoniou, X., Gassmann, M. and Ogunshola, O.O. (2008) Astrocyte responses to injury: VEGF simultaneously modulates cell death and proliferation. American Journal of Physiology - Regulatory, Integrative and Comparative Physiology, 295, R864-R873. doi:10.1152/ajpregu.00536.2007

[27] Seri, B., Garcia-Verdugo, J.M., McEwen, B.S. and Alvarez-Buylla, A. (2001) Astrocytes give rise to new neurons in the adult mammalian hippocampus. Journal of Neuroscience, 21, 7153-7160.

[28] Lang, B. (2004) Astrocytes in injured adult rat spinal cord may acquire the potential of neural stem cells. Neuroscience, 128, 775-783. doi:10.1016/j.neuroscience.2004.06.033

[29] Buffo, A., Rolando, C. and Ceruti, S. (2010) Astrocytes in the damaged brain: Molecular and cellular insights into their reactive response and healing potential. Biochemical Pharmacology, 79, 77-89. doi:10.1016/j.bcp.2009.09.014

[30] Sofroniew, M.V. and Vinters, H.V. (2010) Astrocytes: Biology and pathology. Acta Neuropathologica, 119, 7-35. doi:10.1007/s00401-009-0619-8

[31] Barroca, V., Lassalle, B., Coureuil, M., Louis, J.P., Le Page, F., Testart, J., Allemand, I., Riou, L. and Fouchet, P. (2009) Mouse differentiating spermatogonia can generate germinal stem cells in vivo. Nature Cell Biology, 11, 190196. doi: $10.1038 / \mathrm{ncb} 1826$

[32] Brawley, C. and Matunis, E. (2004) Regeneration of male 
germline stem cells by spermatogonial dedifferentiation in vivo. Science, 304, 1331-1334.

doi:10.1126/science.1097676

[33] Nakagawa, T., Sharma, M., Nabeshima, Y., Braun, R.E. and Yoshida, S. (2010) Functional hierarchy and reversebility within the murine spermatogenic stem cell compartment. Science, 328, 62-67. doi:10.1126/science. 1182868

[34] Mu, X., Peng, H., Pan, H., Huard, J. and Li, Y. (2011) Study of muscle cell dedifferentiation after skeletal muscle injury of mice with a Cre-Lox system. PloS One, 6, Article ID e16699. doi:10.1371/journal.pone.0016699

[35] McGann, C.J., Odelberg, S.J. and Keating, M.T. (2001) Mammalian myotube dedifferentiation induced by newt regeneration extract. Proceedings of the National Academy of Sciences of USA, 98, 13699-13704. doi:10.1073/pnas.221297398

[36] Rosania, G.R., Chang, Y.T., Perez, O., Sutherlin, D., Dong, H., Lockhart, D.J. and Schultz, P.G. (2000) Myoseverin, a microtubule-binding molecule with novel cellular effects. Nature Biotechnology, 18, 304-308. doi:10.1038/73753

[37] Chen, S., Zhang, Q., Wu, X., Schultz, P.G. and Ding, S. (2004) Dedifferentiation of lineage-committed cells by a small molecule. Journal of the American Chemical Society, 126, 410-411. doi:10.1021/ja037390k

[38] Takahashi, K. and Yamanaka, S. (2006) Induction of pluripotent stem cells from mouse embryonic and adult fibroblast cultures by defined factors. Cell, 126, 663-676. doi:10.1016/j.cell.2006.07.024

[39] Okita, K., Ichisaka, T. and Yamanaka, S. (2007) Generation of germline-competent induced pluripotent stem cells. Nature, 448, 313-317. doi:10.1038/nature05934

[40] Takahashi, K., Tanabe, K., Ohnuki, M., Narita, M., Ichisaka, T., Tomoda, K. and Yamanaka, S. (2007) Induction of pluripotent stem cells from adult human fibroblasts by defined factors. Cell, 131, 861-872. doi:10.1016/j.cell.2007.11.019

[41] Park, I.H., Zhao, R., West, J.A., Yabuuchi, A., Huo, H., Ince, T.A., Lerou, P.H., Lensch, M.W. and Daley, G.Q. (2008) Reprogramming of human somatic cells to pluripotency with defined factors. Nature, 451, 141-146. doi:10.1038/nature06534

[42] Yu, J., Vodyanik, M.A., Smuga-Otto, K., Anto0- siewiczBourget, J., Frane, J.L., Tian, S., Nie, J., Jonsdottir, G.A., Ruotti, V., Stewart, R., et al. (2007) Induced pluripotent stem cell lines derived from human somatic cells. Science, 318, 1917-1920. doi:10.1126/science. 1151526

[43] Ramon y Cajal, S. (1913) Degeneration and regeneration of the nervous system. Oxford University Press, London.

[44] Colucci-D'Amato, L., Bonavita, V. and di Porzio, U. (2006) The end of the central dogma of neurobiology: Stem cells and neurogenesis in adult CNS. Neurological Sciences, 27, 266-270. doi:10.1007/s10072-006-0682-Z

[45] Gross, C.G. (2000) Neurogenesis in the adult brain: Death of a dogma. Nature Reviews Neuroscience, 1, 67-73. doi: $10.1038 / 35036235$

[46] Davies, S.J., Fitch, M.T., Memberg, S.P., Hall, A.K., Raisman, G. and Silver, J. (1997) Regeneration of adult ax- ons in white matter tracts of the central nervous system. Nature, 390, 680-683.

[47] Nishio, T. (2009) Axonal regeneration and neural network reconstruction in mammalian CNS. Journal of Neurology, 256, 306-309. doi:10.1007/s00415-009-5244-x

[48] Liu, K., Tedeschi, A., Park, K.K. and He, Z. (2011) Neuronal intrinsic mechanisms of axon regeneration. Annual Review of Neuroscience, 34, 131-152. doi:10.1146/annurev-neuro-061010-113723

[49] Altman, J. and Das, G.D. (1965) Autoradiographic and histological evidence of postnatal hippo campal neurogenesis in rats. The Journal of Comparative Neurology, 124, 319-335. doi:10.1002/cne.901240303

[50] Altman, J. (1969) Autoradiographic and histological studies of postnatal neurogenesis. IV. Cell proliferation and migration in the anterior forebrain, with special reference to persisting neurogenesis in the olfactory bulb. The Journal of Comparative Neurology, 137, 433-457. doi:10.1002/cne.901370404

[51] Altman, J. (1963) Autoradiographic investigation of cell proliferation in the brains of rats and cats. The Anatomical Record, 145, 573-591. doi:10.1002/ar.1091450409

[52] Miller, M.W. and Nowakowski, R.S. (1988) Use of bromodeoxyuridine-immunohistochemistry to examine the proliferation, migration and time of origin of cells in the central nervous system. Brain Research, 457, 44-52. doi:10.1016/0006-8993(88)90055-8

[53] Taupin, P. (2007) Protocols for studying adult neurogenesis: Insights and recent developments. Regenerative $\mathrm{Me}$ dicine, 2, 51-62. doi:10.2217/17460751.2.1.51

[54] Gould, E., Reeves, A.J., Graziano, M.S. and Gross, C.G. (1999) Neurogenesis in the neocortex of adult primates. Science, 286, 548-552. doi:10.1126/science.286.5439.548

[55] Lendahl, U., Zimmerman, L.B. and McKay, R.D. (1990) CNS stem cells express a new class of intermediate filament protein. Cell, 60, 585-595. doi:10.1016/0092-8674(90)90662-X

[56] Mullen, R.J., Buck, C.R. and Smith, A.M. (1992) NeuN, a neuronal specific nuclear protein in vertebrates. Development, 116, 201-211.

[57] Bonfanti, L. (2006) PSA-NCAM in mammalian structural plasticity and neurogenesis. Progress in Neurobiology, 80, 129-164. doi:10.1016/j.pneurobio.2006.08.003

[58] Dhaliwal, J. and Lagace, D.C. (2011) Visualization and genetic manipulation of adult neurogenesis using transgenic mice. European Journal of Neuroscience, 33, 10251036. doi:10.1111/j.1460-9568.2011.07600.x

[59] Yamaguchi, M., Saito, H., Suzuki, M. and Mori, K. (2000) Visualization of neurogenesis in the central nervous system using nestin promoter-GFP transgenic mice. NeuroReport, 11, 1991-1996. doi:10.1097/00001756-200006260-00037

[60] Imayoshi, I., Sakamoto, M. and Kageyama, R. (2011) Genetic methods to identify and manipulate newly born neurons in the adult brain. Frontiers in Neuroscience, 5, 64. doi:10.3389/fnins.2011.00064

[61] Reynolds, B.A. and Weiss, S. (1992) Generation of neurons and astrocytes from isolated cells of the adult mam- 
malian central nervous system. Science, 255, 1707-1710. doi:10.1126/science. 1553558

[62] Gage, F.H. (2000) Mammalian neural stem cells. Science, 287, 1433-1438. doi:10.1126/science.287.5457.1433

[63] Temple, S. (2001) The development of neural stem cells. Nature, 414, 112-117. doi:10.1038/35102174

[64] Ming, G.L. and Song, H. (2011) Adult neurogenesis in the mammalian brain: Significant answers and significant questions. Neuron, 70, 687-702. doi:10.1016/j.neuron.2011.05.001

[65] Ming, G.L. and Song, H. (2005) Adult neurogenesis in the mammalian central nervous system. Annual Review of Neuroscience, 28, 223-250. doi:10.1146/annurev.neuro.28.051804.101459

[66] Kempermann, G. and Gage, F.H. (2000) Neurogenesis in the adult hippocampus. Novartis Foundation Symposium, 231, 220-235, 235-241, 302-226.

[67] Alvarez-Buylla, A. and Garcia-Verdugo, J.M. (2002) Neurogenesis in adult subventricular zone. The Journal of Neuroscience, 22, 629-634.

[68] Shihabuddin, L.S., Horner, P.J., Ray, J. and Gage, F.H. (2000) Adult spinal cord stem cells generate neurons after transplantation in the adult dentate gyrus. The Journal of Neuroscience, 20, 8727-8735.

[69] Horner, P.J., Power, A.E., Kempermann, G., Kuhn, H.G., Palmer, T.D., Winkler, J., Thal, L.J. and Gage, F.H. (2000) Proliferation and differentiation of progenitor cells throughhout the intact adult rat spinal cord. The Journal of Neuroscience, 20, 2218-2228.

[70] Dayer, A.G., Cleaver, K.M., Abouantoun, T. and Cameron, H.A. (2005) New GABAergic interneurons in the adult neocortex and striatum are generated from different precursors. The Journal of Cell Biology, 168, 415-427. doi:10.1083/jcb.200407053

[71] Gould, E., Reeves, A.J., Graziano, M.S. and Gross, C.G. (1999) Neurogenesis in the neocortex of adult primates. Science, 286, 548-552. doi:10.1126/science.286.5439.548

[72] Gould, E., Vail, N., Wagers, M. and Gross, C.G. (2001) Adult-generated hippocampal and neocortical neurons in macaques have a transient existence. Proceedings of the National Academy of Sciences of USA, 98, 10910-10917. doi:10.1073/pnas.181354698

[73] Richardson, W.D., Young, K.M., Tripathi, R.B. and McKenzie, I. (2011) NG2-glia as multipotent neural stem cells: Fact or fantasy? Neuron, 70, 661-673. doi:10.1016/j.neuron.2011.05.013

[74] Rivers, L.E., Young, K.M., Rizzi, M., Jamen, F., Psachoulia, K., Wade, A., Kessaris, N. and Richardson, W.D. (2008) PDGFRA/NG2 glia generate myelinating oligodendrocytes and piriform projection neurons in adult mice. Nature Neuroscience, 11, 1392-1401. doi:10.1038/nn.2220

[75] Guo, F., Maeda, Y., Ma, J., Xu, J., Horiuchi, M., Miers, L., Vaccarino, F. and Pleasure, D. (2010) Pyramidal neurons are generated from oligodendroglial progenitor cells in adult piriform cortex. The Journal of Neuroscience, 30, 12036-12049. doi:10.1523/JNEUROSCI.1360-10.2010

[76] Gould, E. (2007) How widespread is adult neurogenesis in mammals? Nature Reviews Neuroscience, 8, 481-488. doi:10.1038/nrn2147

[77] Breunig, J.J., Arellano, J.I., Macklis, J.D. and Rakic, P. (2007) Everything that glitters isn't gold: A critical review of postnatal neural precursor analyses. Cell Stem Cell, 1, 612-627. doi:10.1016/j.stem.2007.11.008

[78] Nakatomi, H., Kuriu, T., Okabe, S., Yamamoto, S., Hatano, O., Kawahara, N., Tamura, A., Kirino, T. and Nakafuku, M. (2002) Regeneration of hippocampal pyramidal neurons after ischemic brain injury by recruitment of endogenous neural progenitors. Cell, 110, 429-441. doi:10.1016/S0092-8674(02)00862-0

[79] Arvidsson, A., Collin, T., Kirik, D., Kokaia, Z. and Lindvall, O. (2002) Neuronal replacement from endogenous precursors in the adult brain after stroke. Nature Medicine, 8, 963-970. doi:10.1038/nm747

[80] Thored, P., Arvidsson, A., Cacci, E., Ahlenius, H., Kallur, T., Darsalia, V., Ekdahl, C.T., Kokaia, Z. and Lindvall, O. (2006) Persistent production of neurons from adult brain stem cells during recovery after stroke. Stem Cells, 24, 739-747. doi:10.1634/stemcells.2005-0281

[81] Kernie, S.G. and Parent, J.M. (2010) Forebrain neurogenesis after focal ischemic and traumatic brain injury. Neurobiology of Disease, 37, 267-274. doi:10.1016/j.nbd.2009.11.002

[82] Enciu, A.M., Nicolescu, M.I., Manole, C.G., Muresanu, D.F., Popescu, L.M. and Popescu, B.O. (2011) Neuroregeneration in neurodegenerative disorders. BioMedCentral Neurology, 11, 75. doi:10.1186/1471-2377-11-75

[83] Winner, B., Kohl, Z. and Gage, F.H. (2011) Neurodegenerative disease and adult neurogenesis. European Journal of Neuroscience, 33, 1139-1151. doi:10.1111/j.1460-9568.2011.07613.x

[84] Jiang, W., Gu, W., Brannstrom, T., Rosqvist, R. and Wester, P. (2001) Cortical neurogenesis in adult rats after transient middle cerebral artery occlusion. Stroke, 32, 1201-1207. doi:10.1161/01.STR.32.5.1201

[85] Magavi, S.S., Leavitt, B.R. and Macklis, J.D. (2000) Induction of neurogenesis in the neocortex of adult mice. Nature, 405, 951-955. doi:10.1038/35016083

[86] Ohira, K., Furuta, T., Hioki, H., Nakamura, K.C., Kuramoto, E., Tanaka, Y., Funatsu, N., Shimizu, K., Oishi, T., Hayashi, M., et al. (2010) Ischemia-induced neurogenesis of neocortical layer 1 progenitor cells. Nature Neuroscience, 13, 173-179. doi:10.1038/nn.2473

[87] Benraiss, A., Chmielnicki, E., Lerner, K., Roh, D. and Goldman, S.A. (2001) Adenoviral brain-derived neurotrophic factor induces both neostriatal and olfactory neuronal recruitment from endogenous progenitor cells in the adult forebrain. The Journal of Neuroscience, 21, 67186731.

[88] Van Kampen, J.M., Hagg, T. and Robertson, H.A. (2004) Induction of neurogenesis in the adult rat subventricular zone and neostriatum following dopamine D3 receptor stimulation. European Journal of Neuroscience, 19, 2377-2387. doi:10.1111/j.0953-816X.2004.03342.x

[89] Pencea, V., Bingaman, K.D., Wiegand, S.J. and Luskin, M.B. (2001) Infusion of brain-derived neurotrophic factor 
into the lateral ventricle of the adult rat leads to new neurons in the parenchyma of the striatum, septum, thalamus, and hypothalamus. The Journal of Neuroscience, 21, 6706-6717.

[90] Park, J.H., Cho, H., Kim, H. and Kim, K. (2006) Repeated brief epileptic seizures by pentylenetetrazole cause neurodegeneration and promote neurogenesis in discrete brain regions of freely moving adult rats. Neuroscience, 140, 673-684. doi:10.1016/j.neuroscience.2006.02.076

[91] Kokoeva, M.V., Yin, H. and Flier, J.S. (2005) Neurogenesis in the hypothalamus of adult mice: Potential role in energy balance. Science, 310, 679-683. doi:10.1126/science. 1115360

[92] Migaud, M., Batailler, M., Segura, S., Duittoz, A., Franceschini, I. and Pillon, D. (2010) Emerging new sites for adult neurogenesis in the mammalian brain: A comparative study between the hypothalamus and the classical neurogenic zones. European Journal of Neuroscience, 32, 2042-2052. doi:10.1111/j.1460-9568.2010.07521.x

[93] Zhao, M., Momma, S., Delfani, K., Carlen, M., Cassidy, R.M., Johansson, C.B., Brismar, H., Shupliakov, O., Frisen, J. and Janson, A.M. (2003) Evidence for neurogenesis in the adult mammalian substantia nigra. Proceedings of the National Academy of Sciences of USA, 100, 7925-7930. doi:10.1073/pnas.1131955100

[94] Van Kampen, J.M. and Robertson, H.A. (2005) A possible role for dopamine D3 receptor stimulation in the induction of neurogenesis in the adult rat substantia nigra. Neuroscience, 136, 381-386.

doi:10.1016/i.neuroscience.2005.07.054

[95] Zheng, Y., Begum, S., Zhang, C., Fleming, K., Masumura, C., Zhang, M., Smith, P. and Darlington, C. (2011) Increased BrdU incorporation reflecting DNA repair, neuronal dedifferentiation or possible neurogenesis in the adult cochlear nucleus following bilateral cochlear lesions in the rat. Experimental Brain Research, 210, 477-487. doi:10.1007/s00221-010-2491-0

[96] Charrier, C., Coronas, V., Fombonne, J., Roger, M., Jean, A., Krantic, S. and Moyse, E. (2006) Characterization of neural stem cells in the dorsal vagal complex of adult rat by in vivo proliferation labeling and in vitro neurosphere assay. Neuroscience, 138, 5-16. doi:10.1016/j.neuroscience.2005.10.046

[97] Fagerlund, M., Jaff, N., Danilov, A.I., Peredo, I., Brundin, L. and Svensson, M. (2011) Proliferation, migration and differentiation of ependymal region neural progenitor cells in the brainstem after hypoglossal nerve avulsion. Restorative Neurology and Neuroscience, 29, 47-59.

[98] Okano, H., Sakaguchi, M., Ohki, K., Suzuki, N. and Sawamoto, K. (2007) Regeneration of the central nervous system using endogenous repair mechanisms. Journal of Neurochemistry, 102, 1459-1465. doi:10.1111/j.1471-4159.2007.04674.x

[99] Robel, S., Berninger, B. and Gotz, M. (2011) The stem cell potential of glia: Lessons from reactive gliosis. $\mathrm{Na}$ ture Reviews Neuroscience, 12, 88-104. doi:10.1038/nrn2978

[100] Benchoua, A. and Onteniente, B. (2011) Intracerebral transplantation for neurological disorders. Lessons from developmental, experimental, and clinical studies. Frontiers in Cellular Neuroscience, $\mathbf{6}, 2$.

[101] Martino, G. and Pluchino, S. (2006) The therapeutic potential of neural stem cells. Nature Reviews Neuroscience, 7, 395-406. doi:10.1038/nrn1908

[102] Schouten, J.W., Fulp, C.T., Royo, N.C., Saatman, K.E., Watson, D.J., Snyder, E.Y., Trojanowski, J.Q., Prockop, D.J., Maas, A.I. and McIntosh, T.K. (2004) A review and rationale for the use of cellular transplantation as a therapeutic strategy for traumatic brain injury. Journal of $\mathrm{Neu}$ rotrauma, 21, 1501-1538. doi:10.1089/neu.2004.21.1501

[103] Enzmann, G.U., Benton, R.L., Talbott, J.F., Cao, Q. and Whittemore, S.R. (2006) Functional considerations of stem cell transplantation therapy for spinal cord repair. Journal of Neurotrauma, 23, 479-495. doi:10.1089/neu.2006.23.479

[104] Liu, F., You, Y., Li, X., Ma, T., Nie, Y., Wei, B., Li, T., Lin, H. and Yang, Z. (2009) Brain injury does not alter the intrinsic differentiation potential of adult neuroblasts. The Journal of Neuroscience, 29, 5075-5087. doi:10.1523/JNEUROSCI.0201-09.2009

[105] Guillemot, F. and Zimmer, C. (2011) From cradle to grave: The multiple roles of fibroblast growth factors in neural development. Neuron, 71, 574-588. doi:10.1016/j.neuron.2011.08.002

[106] Chaichana, K., Zamora-Berridi, G., Camara-Quintana, J. and Quinones-Hinojosa, A. (2006) Neurosphere assays: Growth factors and hormone differences in tumor and nontumor studies. Stem Cells, 24, 2851-2857. doi:10.1634/stemcells.2006-0399

[107] Bath, K.G. and Lee, F.S. (2010) Neurotrophic factor control of adult SVZ neurogenesis. Developmental Neurobiology, 70, 339-349.

[108] Hagg, T. (2009) From neurotransmitters to neurotrophic factors to neurogenesis. The Neuroscientist, 15, 20-27. doi: $10.1177 / 1073858408324789$

[109] Barros, C.S., Franco, S.J. and Muller, U. (2011) Extracellular matrix: Functions in the nervous system. Cold Spring Harbor Perspectives in Biology, 3, Article ID: a005108. doi:10.1101/cshperspect.a005108

[110] Busch, S.A. and Silver, J. (2007) The role of extracellular matrix in CNS regeneration. Current Opinion in Neurobiology, 17, 120-127. doi:10.1016/j.conb.2006.09.004

[111] Yong, V.W. (2005) Metalloproteinases: Mediators of pathology and regeneration in the CNS. Nature Reviews Neuroscience, 6, 931-944. doi:10.1038/nrn1807

[112] Candelario-Jalil, E., Yang, Y. and Rosenberg, G.A. (2009) Diverse roles of matrix metalloproteinases and tissue inhibitors of metalloproteinases in neuroinflammation and cerebral ischemia. Neuroscience, 158, 983-994. doi:10.1016/j.neuroscience.2008.06.025

[113] Cunningham, L.A., Wetzel, M. and Rosenberg, G.A. (2005) Multiple roles for MMPs and TIMPs in cerebral ischemia. Glia, 50, 329-339. doi:10.1002/glia.20169

[114] Platel, J.C., Stamboulian, S., Nguyen, I. and Bordey, A. (2010) Neurotransmitter signaling in postnatal neurogenesis: The first leg. Brain Research Reviews, 63, 60-71. doi:10.1016/j.brainresrev.2010.02.004 
[115] O'Keeffe, G.C., Barker, R.A. and Caldwell, M.A. (2009) Dopaminergic modulation of neurogenesis in the subventricular zone of the adult brain. Cell Cycle, 8, 2888-2894. doi:10.4161/cc.8.18.9512

[116] Shen, Q., Goderie, S.K., Jin, L., Karanth, N., Sun, Y., Abramova, N., Vincent, P., Pumiglia, K. and Temple, S. (2004) Endothelial cells stimulate self-renewal and expand neurogenesis of neural stem cells. Science, 304, 1338-1340. doi:10.1126/science.1095505

[117] Yang, X.T., Bi, Y.Y. and Feng, D.F. (2011) From the vascular microenvironment to neurogenesis. Brain Research Bulletin, 84, 1-7. doi:10.1016/j.brainresbull.2010.09.008

[118] Quaegebeur, A., Lange, C. and Carmeliet, P. (2011) The neurovascular link in health and disease: Molecular mechanisms and therapeutic implications. Neuron, 71, 406-424. doi:10.1016/j.neuron.2011.07.013

[119] Rolls, A., Shechter, R. and Schwartz, M. (2009) The bright side of the glial scar in CNS repair. Nature Reviews Neuroscience, 10, 235-241. doi:10.1038/nrn2591

[120] Silver, J. and Miller, J.H. (2004) Regeneration beyond the glial scar. Nature Reviews Neuroscience, 5, 146-156. doi:10.1038/nrn1326

[121] Okouchi, M., Ekshyyan, O., Maracine, M. and Aw, T.Y. (2007) Neuronal apoptosis in neurodegeneration. Antioxidants \& Redox Signaling, 9, 1059-1096. doi:10.1089/ars.2007.1511

[122] Bauer, S. and Patterson, P.H. (2005) The cell cycleapoptosis connection revisited in the adult brain. The Journal of Cell Biology, 171, 641-650. doi:10.1083/jcb.200505072

[123] Carpentier, P.A. and Palmer, T.D. (2009) Immune influence on adult neural stem cell regulation and function. Neuron, 64, 79-92. doi:10.1016/j.neuron.2009.08.038

[124] Russo, I., Barlati, S. and Bosetti, F. (2011) Effects of neuroinflammation on the regenerative capacity of brain stem cells. Journal of Neurochemistry, 116, 947-956. doi:10.1111/j.1471-4159.2010.07168.x

[125] Kuhn, H.G., Dickinson-Anson, H. and Gage, F.H. (1996) Neurogenesis in the dentate gyrus of the adult rat: Age-related decrease of neuronal progenitor proliferation. Journal of Neurochemistry, 16, 2027-2033.

[126] Driscoll, I., Howard, S.R., Stone, J.C., Monfils, M.H., Tomanek, B., Brooks, W.M. and Sutherland, R.J. (2006) The aging hippocampus: A multi-level analysis in the rat. Neuroscience, 139, 1173-1185. doi:10.1016/j.neuroscience.2006.01.040

[127] Cao, Q., He, Q., Wang, Y., Cheng, X., Howard, R.M., Zhang, Y., DeVries, W.H., Shields, C.B., Magnuson, D.S., $\mathrm{Xu}, \mathrm{X} . \mathrm{M}$. , et al. (2010) Transplantation of ciliary neurotrophic factor-expressing adult oligodendrocyte precursor cells promotes remyelination and functional recovery after spinal cord injury. Journal of Neurochemistry, 30, 2989-3001. doi:10.1523/JNEUROSCI.3174-09.2010

[128] Hayon, Y., Dashevsky, O., Shai, E., Varon, D. and Leker, R.R. (2012) Platelet microparticles promote neural stem cell proliferation, survival and differentiation. Journal of Molecular Neuroscience, 47, 659-665.

[129] Bambakidis, N.C., Petrullis, M., Kui, X., Rothstein, B.,
Karampelas, I., Kuang, Y., Selman, W.R., Lamanna, J.C. and Miller, R.H. (2012) Improvement of neurological recovery and stimulation of neural progenitor cell proliferation by intrathecal administration of sonic hedgehog. Journal of Neurosurgery, 116, 1114-1120. doi:10.3171/2012.1.JNS111285

[130] Ekdahl, C.T., Claasen, J.H., Bonde, S., Kokaia, Z. and Lindvall, O. (2003) Inflammation is detrimental for neurogenesis in adult brain. Proceedings of the National Academy of Sciences of USA, 100, 13632-13637. doi:10.1073/pnas.2234031100

[131] Edwards, P., Arango, M., Balica, L., Cottingham, R., El-Sayed, H., Farrell, B., Fernandes, J., Gogichaisvili, T. Golden, N., Hartzenberg, B., et al. (2005) Final results of MRC CRASH, a randomised placebo-controlled trial of intravenous corticosteroid in adults with head injuryoutcomes at 6 months. The Lancet, 365, 1957-1959. doi:10.1016/S0140-6736(05)66552-X

[132] Monje, M.L., Toda, H. and Palmer, T.D. (2003) Inflammatory blockade restores adult hippocampal neurogenesis. Science, 302, 1760-1765. doi:10.1126/science.1088417

[133] Madrazo, I., Drucker-Colin, R., Diaz, V., Martinez-Mata, J., Torres, C. and Becerril, J.J. (1987) Open microsurgical autograft of adrenal medulla to the right caudate nucleus in two patients with intractable Parkinson's disease. The New England Journal of Medicine, 316, 831-834. doi:10.1056/NEJM198704023161402

[134] Bachoud-Levi, A.C., Gaura, V., Brugieres, P., Lefaucheur, J.P., Boisse, M.F., Maison, P., Baudic, S., Ribeiro, M.J., Bourdet, C., Remy, P., et al. (2006) Effect of fetal neural transplants in patients with Huntington's disease 6 years after surgery: A long-term follow-up study. The Lancet Neurology, 5, 303-309. doi:10.1016/S1474-4422(06)70381-7

[135] Freed, C.R., Greene, P.E., Breeze, R.E., Tsai, W.Y., DuMouchel, W., Kao, R., Dillon, S., Winfield, H., Culver, S., Trojanowski, J.Q., et al. (2001) Transplantation of embryonic dopamine neurons for severe Parkinson's disease. The New England Journal of Medicine, 344, 710719. doi:10.1056/NEJM200103083441002

[136] Olanow, C.W., Goetz, C.G., Kordower, J.H., Stoessl, A.J., Sossi, V., Brin, M.F., Shannon, K.M., Nauert, G.M., Perl, D.P., Godbold, J., et al. (2003) A double-blind controlled trial of bilateral fetal nigral transplantation in Parkinson's disease. Annals of Neurology, 54, 403-414. doi:10.1002/ana.10720

[137] Johe, K.K., Hazel, T.G., Muller, T., Dugich-Djordjevic, M.M. and McKay, R.D. (1996) Single factors direct the differentiation of stem cells from the fetal and adult central nervous system. Genes \& Development, 10, 31293140. doi:10.1101/gad.10.24.3129

[138] Tamaki, S.J., Jacobs, Y., Dohse, M., Capela, A., Cooper, J.D., Reitsma, M., He, D., Tushinski, R., Belichenko, P.V., Salehi, A., et al. (2009) Neuroprotection of host cells by human central nervous system stem cells in a mouse model of infantile neuronal ceroid lipofuscinosis. Cell Stem Cell, 5, 310-319. doi:10.1016/j.stem.2009.05.022

[139] Miljan, E.A. and Sinden, J.D. (2009) Stem cell treatment of ischemic brain injury. Current Opinion in Molecular 
Therapeutics, 11, 394-403.

[140] Zhu, J., Zhou, L. and XingWu, F. (2006) Tracking neural stem cells in patients with brain trauma. The New England Journal of Medicine, 355, 2376-2378. doi:10.1056/NEJMc055304

[141] Amariglio, N., Hirshberg, A., Scheithauer, B.W., Cohen, Y., Loewenthal, R., Trakhtenbrot, L., Paz, N., KorenMichowitz, M., Waldman, D., Leider-Trejo, L., et al. (2009) Donor-derived brain tumor following neural stem cell transplantation in an ataxia telangiectasia patient. PLoS Medicine, 6, Article ID e1000029. doi:10.1371/journal.pmed.1000029

[142] Evans, M. (2011) Discovering pluripotency: 30 years of mouse embryonic stem cells. Nature Reviews Molecular Cell Biology, 12, 680-686. doi:10.1038/nrm3190

[143] Soundararajan, P., Lindsey, B.W., Leopold, C. and Rafuse, V.F. (2007) Easy and rapid differentiation of embryonic stem cells into functional motoneurons using sonic hedgehog-producing cells. Stem Cells, 25, 1697-1706. doi:10.1634/stemcells.2006-0654

[144] Lee, H., Shamy, G.A., Elkabetz, Y., Schofield, C.M., Harrsion, N.L., Panagiotakos, G., Socci, N.D., Tabar, V. and Studer, L. (2007) Directed differentiation and transplantation of human embryonic stem cell-derived motoneurons. Stem Cells, 25, 1931-1939. doi:10.1634/stemcells.2007-0097

[145] Kriks, S., Shim, J.W., Piao, J., Ganat, Y.M., Wakeman, D.R., Xie, Z., Carrillo-Reid, L., Auyeung, G., Antonacci, C., Buch, A., et al. (2011) Dopamine neurons derived from human ES cells efficiently engraft in animal models of Parkinson's disease. Nature, 480, 547-551.

[146] Weick, J.P., Liu, Y. and Zhang, S.C. (2011) Human embryonic stem cell-derived neurons adopt and regulate the activity of an established neural network. Proceedings of the National Academy of Sciences of USA, 108, 2018920194. doi:10.1073/pnas.1108487108

[147] Doi, D., Morizane, A., Kikuchi, T., Onoe, H., Hayashi, T., Kawasaki, T., Motono, M., Sasai, Y., Saiki, H., Gomi, M., et al. (2012) Prolonged maturation culture favors a reduction in the tumorigenicity and the dopaminergic function of human esc-derived neural cells in a primate model of parkinson's disease. Stem Cells, 30, 935-945.

[148] Guhr, A., Kurtz, A., Friedgen, K. and Loser, P. (2006) Current state of human embryonic stem cell research: An overview of cell lines and their use in experimental work. Stem Cells, 24, 2187-2191. doi:10.1634/stemcells.2006-0053

[149] Plath, K. and Lowry, W.E. (2011) Progress in understanding reprogramming to the induced pluripotent state. Nature Reviews Genetics, 12, 253-265. doi:10.1038/nrg2955

[150] Kim, K., Doi, A., Wen, B., Ng, K., Zhao, R., Cahan, P., Kim, J., Aryee, M.J., Ji, H., Ehrlich, L.I., et al. (2010) Epigenetic memory in induced pluripotent stem cells. Nature, 467, 285-290. doi:10.1038/nature09342

[151] Bilic, J. and Izpisua Belmonte, J.C. (2012) Concise review: Induced pluripotent stem cells versus embryonic stem cells: Close enough or yet too far apart? Stem Cells, 30, 33-41. doi: $10.1002 /$ stem.700
[152] Schwartz, P.H., Brick, D.J., Stover, A.E., Loring, J.F. and Muller, F.J. (2008) Differentiation of neural lineage cells from human pluripotent stem cells. Methods, 45, 142-158. doi:10.1016/j.ymeth.2008.03.007

[153] Vierbuchen, T., Ostermeier, A., Pang, Z.P., Kokubu, Y., Sudhof, T.C. and Wernig, M. (2010) Direct conversion of fibroblasts to functional neurons by defined factors. $\mathrm{Na}$ ture, 463, 1035-1041. doi:10.1038/nature08797

[154] Caiazzo, M., Dell'Anno, M.T., Dvoretskova, E., Lazarevic, D., Taverna, S., Leo, D., Sotnikova, T.D., Menegon, A., Roncaglia, P., Colciago, G., et al. (2011) Direct generation of functional dopaminergic neurons from mouse and human fibroblasts. Nature, 476, 224-227. doi:10.1038/nature 10284

[155] Kim, J., Efe, J.A., Zhu, S., Talantova, M., Yuan, X., Wang, S., Lipton, S.A., Zhang, K. and Ding, S. (2011) Direct reprogramming of mouse fibroblasts to neural progenitors. Proceedings of the National Academy of Sciences of USA, 108, 7838-7843. doi:10.1073/pnas.1103113108

[156] Yang, N., Ng, Y.H., Pang, Z.P., Sudhof, T.C. and Wernig, M. (2011) Induced neuronal cells: How to make and define a neuron. Cell Stem Cell, 9, 517-525. doi:10.1016/j.stem.2011.11.015

[157] Marro, S., Pang, Z.P., Yang, N., Tsai, M.C., Qu, K., Chang, H.Y., Sudhof, T.C. and Wernig, M. (2011) Direct lineage conversion of terminally differentiated hepatocytes to functional neurons. Cell Stem Cell, 9, 374-382. doi:10.1016/j.stem.2011.09.002

[158] Son, E.Y., Ichida, J.K., Wainger, B.J., Toma, J.S., Rafuse, V.F., Woolf, C.J. and Eggan, K. (2011) Conversion of mouse and human fibroblasts into functional spinal motor neurons. Cell Stem Cell, 9, 205-218. doi:10.1016/j.stem.2011.07.014

[159] Pang, Z.P., Yang, N., Vierbuchen, T., Ostermeier, A., Fuentes, D.R., Yang, T.Q., Citri, A., Sebastiano, V., Marro, S., Sudhof, T.C., et al. (2011) Induction of human neuronal cells by defined transcription factors. Nature, 476, 220-223.

[160] Wislet-Gendebien, S., Wautier, F., Leprince, P. and Rogister, B. (2005) Astrocytic and neuronal fate of mesenchymal stem cells expressing nestin. Brain Research Bulletin, 68, 95-102. doi:10.1016/j.brainresbull.2005.08.016

[161] Krabbe, C., Zimmer, J. and Meyer, M. (2005) Neural transdifferentiation of mesenchymal stem cells: A critical review. Acta Pathologica, Microbiologica et Immunologica, 113, 831-844. doi:10.1111/j.1600-0463.2005.apm 3061.x

[162] Romero-Ramos, M., Vourch, P., Young, H.E., Lucas, P.A., Wu, Y., Chivatakarn, O., Zaman, R., Dunkelman, N., elKalay, M.A. and Chesselet, M.F. (2002) Neuronal differentiation of stem cells isolated from adult muscle. Journal of Neuroscience Research, 69, 894-907. doi:10.1002/jnr.10374

[163] Kondo, T., Case, J., Srour, E.F. and Hashino, E. (2006) Skeletal muscle-derived progenitor cells exhibit neural competence. NeuroReport, 17, 1-4. doi:10.1097/01.wnr.0000192732.00535.ff

[164] Alessandri, G., Pagano, S., Bez, A., Benetti, A., Pozzi, S., 
Iannolo, G., Baronio, M., Invernici, G., Caruso, A., Muneretto, C., et al. (2004) Isolation and culture of human muscle-derived stem cells able to differentiate into myogenic and neurogenic cell lineages. The Lancet, 364, 1872-1883. doi:10.1016/S0140-6736(04)17443-6

[165] Herranz, A.S., Gonzalo-Gobernado, R., Reimers, D., Asensio, M.J., Rodriguez-Serrano, M. and Bazan, E. (2010) Applications of human umbilical cord blood cells in central nervous system regeneration. Current Stem Cell Research \& Therapy, 5, 17-22. doi: $10.2174 / 157488810790442822$

[166] Slovinska, L., Novotna, I., Kubes, M., Radonak, J., Jergova, S., Cigankova, V., Rosocha, J. and Cizkova, D. (2011) Umbilical cord blood cells CD133 ${ }^{+} / \mathrm{CD} 133^{-}$cultivation in neural proliferation media differentiates towards neural cell lineages. Archives of Medical Research, 42, 555-562. doi:10.1016/j.arcmed.2011.10.003

[167] Amoh, Y., Kanoh, M., Niiyama, S., Hamada, Y., Kawahara, K., Sato, Y., Hoffman, R.M. and Katsuoka, K. (2009) Human hair follicle pluripotent stem (hfPS) cells promote regeneration of peripheral-nerve injury: An advantageous alternative to ES and iPS cells. Journal of Cellular Biochemistry, 107, 1016-1020. doi:10.1002/jcb.22204

[168] Kwon, E.B., Lee, J.Y., Piao, S., Kim, I.G. and Ra, J.C. (2011) Comparison of human muscle-derived stem cells and human adipose-derived stem cells in neurogenic trans-differentiation. Korean Journal of Urology, 52, 852-

\section{7. doi:10.4111/kju.2011.52.12.852}

[169] Locke, M., Feisst, V. and Dunbar, P.R. (2011) Concise review: Human adipose-derived stem cells: Separating promise from clinical need. Stem Cells, 29, 404-411. doi: $10.1002 /$ stem.593

[170] Salem, H.K. and Thiemermann, C. (2010) Mesenchymal stromal cells: Current understanding and clinical status. Stem Cells, 28, 585-596.

[171] Cox, C.S. Jr., Baumgartner, J.E., Harting, M.T., Worth, L.L., Walker, P.A., Shah, S.K., Ewing-Cobbs, L., Hasan, K.M., Day, M.C., Lee, D., et al. (2011) Autologous bone marrow mononuclear cell therapy for severe traumatic brain injury in children. Neurosurgery, 68, 588-600. doi:10.1227/NEU.0b013e318207734c

[172] Liu, Y., Jiang, X., Zhang, X., Chen, R., Sun, T., Fok, K.L., Dong, J., Tsang, L.L., Yi, S., Ruan, Y., et al. (2011) Dedifferentiation-reprogrammed mesenchymal stem cells with improved therapeutic potential. Stem Cells, 29, 2077-2089. doi:10.1002/stem.764

[173] Raff, M. (2003) Adult stem cell plasticity: Fact or artifact? Annual Review of Cell and Developmental Biology, 19, 122. doi:10.1146/annurev.cellbio.19.111301.143037

[174] Wagers, A.J. and Weissman, I.L. (2004) Plasticity of adult stem cells. Cell, 116, 639-648. doi:10.1016/S0092-8674(04)00208-9 